GANDRUNG: Jurnal Pengabdian Kepada Masyarakat ISSN: 2721-6136 (Online)

\title{
NUTRITION IN IMPROVING BODY IMMUNITY AS AN EFFORT PROTECTION OF COVID-19 FOR TEACHERS OF SMP NEGERI 1 PERAK JOMBANG
}

\author{
Suharti \\ Universitas PGRI Adibuana Surabaya \\ Email: suharti@unipasby.ac.id \\ doi) https://doi.org/10.36526/gandrung.v2i2.1175
}

\begin{abstract}
Currently, almost all countries are facing disease outbreaks caused by the SARS CoV-2 (covid19) virus, based on the data on the Covid-19 distribution map in Indonesia, infected with Covid-19 543,975, recovered 454,879 (83.6\%) and 17,081 died (3.1.\%), Based on the distribution of zoning national data, Jombang is one of the cities where almost all of its territory is included in the red zone, the number of people confirmed as positive is 3,626 people, recovered 3,182 people, treated 100 people and 344 people died, from this data it is necessary socialization of understanding about the importance of increasing body immunity during a pandemic like now. Socialization is carried out through the PPM (community service) program. This activity was carried out at SMP Negeri 1 Perak Jombang, the main target of participating in this activity was the guardian of the students but because they did not get permission, this activity was followed by the teacher and carried out online. The method of implementing the PPM program is based on field observations (observation), counseling (socialization) and the provision of vitamin C assistance. The impact of PPM activities is to increase the knowledge of teachers at SMPN Perak Jombang about the importance of increasing immunity in the pandemic era by consuming nutritious food and regularly consuming Vitamin $\mathrm{C}$. The conclusion is that this socialization activity received a positive response from the teachers and the results of these activities are planned to be disseminated to students through learning.
\end{abstract}

Keyword: PPM,Corona Virus, Nutrition

\section{Pendahuluan}

Saat ini hampir di seluruh negara, tengah menghadapi wabah atau penyakit yang disebabkan virus SARS CoV-2 yang kemudian oleh WHO disepakati dengan nama Corona Virus disingkat Covid-19 (WHO, 2020). Covid-19 merupakan penyakit menular yang menyebabkan penderita dapat mengalami demam, batuk kering, sakit tenggorokan, kehilangan indra perasa dan penciuman hingga kesulitan bernafas. Pada penderita yang rentan penyakit ini dapat berujung pada pneumonia dan kegagalan multiorgan. Infeksi menyebar dari satu orang ke orang lain melalui percikan (droplet) dari saluran pernafasan yang sering dihasilkan saat batuk atau bersin (Hui, DS et al., 2020). Berdasarkan data peta sebaran Covid-19 di Indonesia sebanyak 543.975 orang terkonfirmasi terinfeksi Covid-19, 454.879 orang sembuh (83,6\%) dan sebanyak 17.081 orang meninggal (31\%).

Semenjak Covid-19 diumumkan sebagai pandemi oleh WHO, masyarakat di seluruh dunia termasuk di Indonesia dihimbau dan dipaksa untuk melakukan karantina, sehingga menyebabkan 
GANDRUNG: Jurnal Pengabdian Kepada Masyarakat ISSN: 2721-6136 (Online)

berbagai sektor kegiatan terhenti termasuk didalamnya dunia pendidikan. Proses belajar mengajar yang sedianya dilakukan secara konvensional dengan bertatap muka di lingkungan sekolah, saat ini digantikandengan proses belajar mengajar dari rumah melalui pembelajaran daring atau jarak jauh, sesuai dengan edaran Menteri Pendidikan dan Kebudayaan Republik Indonesia Nomor 4 tahun 2020 tentang "Pelaksanaan Kebijakan Pendidikan Dalam Masa Darurat Penyebaran Coronavirus Disease (Covid-19). Pembelajaran daring ini membuat murid merasa stress dan bosan sehingga mendorong mereka mencari makanan yang manis untuk mengurangi stress (Yilmas, C., 2020).

Makanan manis dapat meningkatkan resiko obesitas yang mengakibatkan penyakit jantung, diabetes, paru-paru. Penyakit tersebut terbukti meningkatkan resiko komplikasi yang lebih serius pada Covid-19 (Wu, C et al., 2020). Namun selain itu tubuh harus diberikan asupan nutrisi yang tepat untuk tubuh bagi orang yang belum terinfeksi maupun pada orang yang telah terinfeksi melalui berbagai zat gizi makro dan mikro. Hal tersebut telah terbukti berperan dalam meningkatkan imunitas tubuh (Gombart, Adrian et al., 2020). Dalam upaya meningkatkan imunitas tubuh di tengah pandemi ini mengkonsumsi makanan bergizi dan vitamin menjadi salah satu cara yang sangat dianjurkan, Vitamin C mempunyai peran dalam pembentukan hemoglobin dalam darah, hal tersebut akan membantu penyerapan zat besi dari makanan sehingga dapat diproses menjadi sel darah merah kembali. Kekurangan vitamin C dikaitkan dengan meningkatnya kerentanan terhadap infeksi, dan respon imun yang kurang kuat. Orang yang kekurangan vitamin $\mathrm{C}$ lebih beresiko terkena virus corona atau Covid-19 karena kekebalan tubuhnya menurun. Kebutuhan vitamin C bergantung pada usia dan jenis kelamin (Agustina; 2015). Mengingat pentingnya peranan nutrisi dalam meningkatkan imunitas tubuh sebagai salah satu tindakan pencegahan penyebaran Covid-19, maka dari itu dirasa perlu untuk memberikan penyuluhan, memberikan bantuan vitamin C di lingkungan SMP Negeri 1 Perak Jombang.

\section{Metode}

Metode pelaksanaan pada PPM (pengabdian pada masyarakat) dibagi menjadi 2 tahap, yang pertama berdasarkan pengamatan di lapangan (observasi), kedua penyuluhan (sosialisasi) dan pemberian bantuan vitamin C.Menurut Sugiyono (2012), observasi sebagai teknik pengumpulan data yang mempunyai ciri yang spesifik karena tidak terbatas pada orang, tetapi juga objek-objek alam lainnya.Tahap observasibertujuan untuk mengamati keadaan lingkungan dan mencari kesepakatan waktu pelaksanaan PPM. Berdasarkan sebaran zonasi data nasional Jombang adalah salah satu kota yang hampir seluruh wilayahnya masuk dalam zona merah, jumlah terkonfirmasi positif 3.626 orang, sembuh 3.182 orang, dirawat 100 orang dan 344 orang meninggal. Dari data tersebut perlu adanya 
GANDRUNG: Jurnal Pengabdian Kepada Masyarakat ISSN: 2721-6136 (Online)

sosialisasi pemahaman tentang pentingnya peningkatan imunitas tubuh pada saat pandemi seperti sekarang ini, oleh karena itu pelaksanaan kegiatan PPM (pengabdian pada masyarakat)di tetapkan di SMP Negeri 1 Perak Jombang Jawa Timur. Kegiatan ini dilaksanakan dalam bentuk penyuluhan (sosialisasi) diawali dengan pemaparan materi, dan diskusi dengan pendampingan para dosen.

\section{Hasil dan Diskusi}

Untuk mengurangi meningkatnya penyebaran kasus covid-19 perlu adanya kesadaran masyarakat untuk mematuhi protokol kesehatan dengan mencuci tangan, memakai masker, menjaga jarak, menghindari kerumunan, mengurangi intensitas diluar rumah, dan mengkonsumsi makanan yang sehat bergizi. Intensitas kesembuhan Covid-19 di Jombang menunjukkan peningkatan, artinya penyakit ini dapat dilawan dengan menjaga imunitas dan menjaga pola kesehatan yang baik,Kegiatan PPM yang dilaksanakan di SMPN 1 Perak diisi dengan kegiatan penyuluhan dan pemberian bantuan vitamin $\mathrm{C}$, harapannya kegiatan ini dapat meningkatkan pengetahuan guru-guru untuk menjaga imunitas tubuh yang baik. KegiatanPPM ini tidakdapatdilaksanakan secara langsung, mengingat kondisi pandemi seperti sekarang, membatasi adanya kegiatan yang sifatnya mengumpulkan massa, untuk itu pelaksanaan PPM kali ini dilakukan secara daring. Panitia pelaksanaan PPM dibagi menjadi dua tempat yaitu di SMPN 1 Perak Jombang yang bertugas mendampingi guru-guru dalam pelaksanaan daring sebanyak 4 orang dosen dan para dosen yang mengikuti kegiatan di Universitas PGRI Adibuana Surabaya. Kegiatan PPM ini memperoleh manfaat peningkatan pengetahuan guru-guru di SMPN 1 Perak Jombang tentang pentingnya meningkatkan kekebalan tubuh di era pandemi dengan mengkonsumsi makanan bergizi dan rutin mengkonsumsi Vitamin C.Kegiatan ini mendapat respon yang positif dari guruguru dan hasil dari kegiatan tersebut direncanakan akan disosialisasikan pada peserta didik melalui pembelajaran. 
GANDRUNG: Jurnal Pengabdian Kepada Masyarakat ISSN: 2721-6136 (Online)

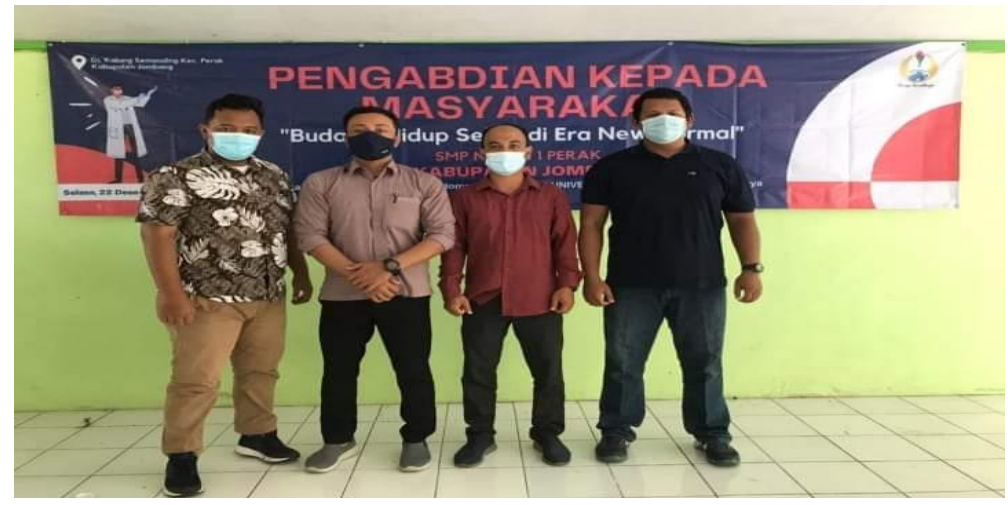

Gambar 1. Panitia yang bertugas diSMP Negeri 1 Perak Jombang

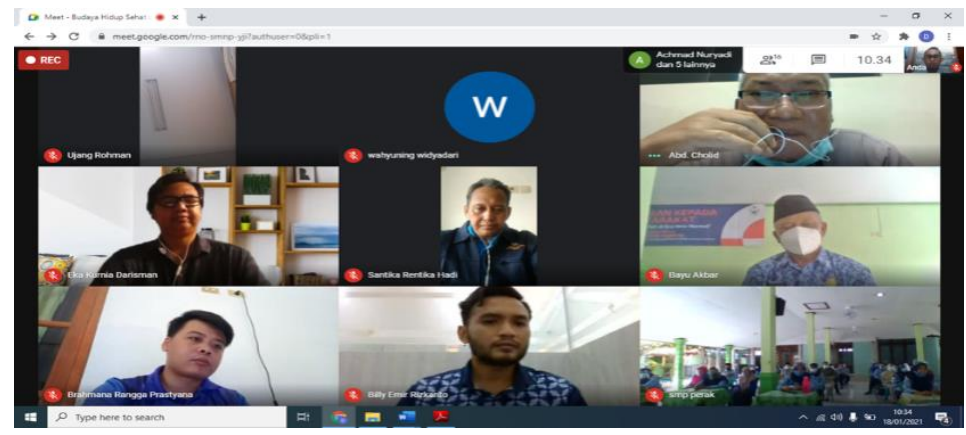

Gambar 2. Panitia yang bertugas di Prodi Pedidikan Jasmani

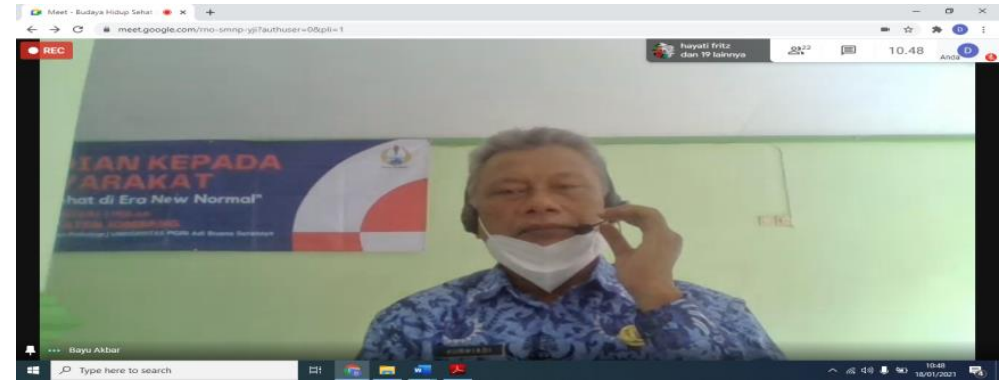

Gambar 3. Sambutan Kepala Sekolah SMP Negeri 1 Perak Jombang

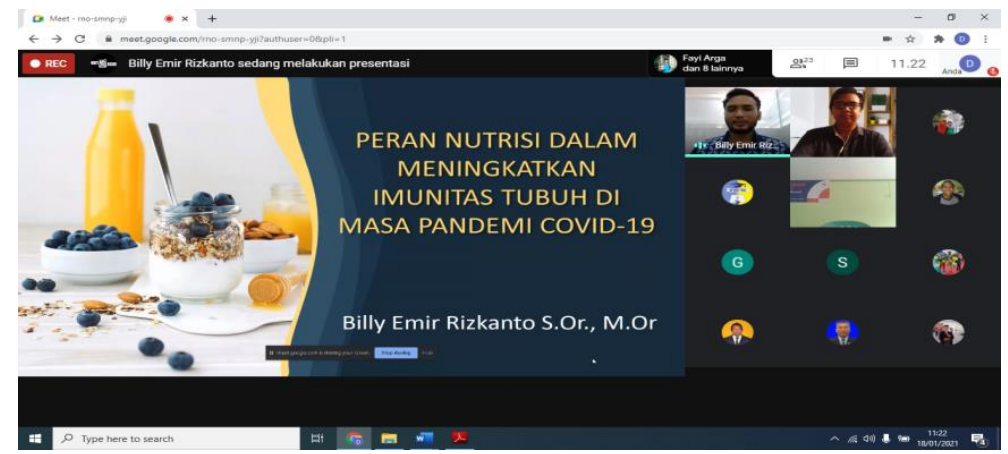

Gambar 4. Pemaparan Materi

Volume 2, Number 2, Juli $2021 \mid 195$ Nutrition In Improving Body Immunity As An Effort Protection Of Covid-19 For Teachers Of Smp Negeri 1 Perak Jombang 
GANDRUNG: Jurnal Pengabdian Kepada Masyarakat ISSN: 2721-6136 (Online)

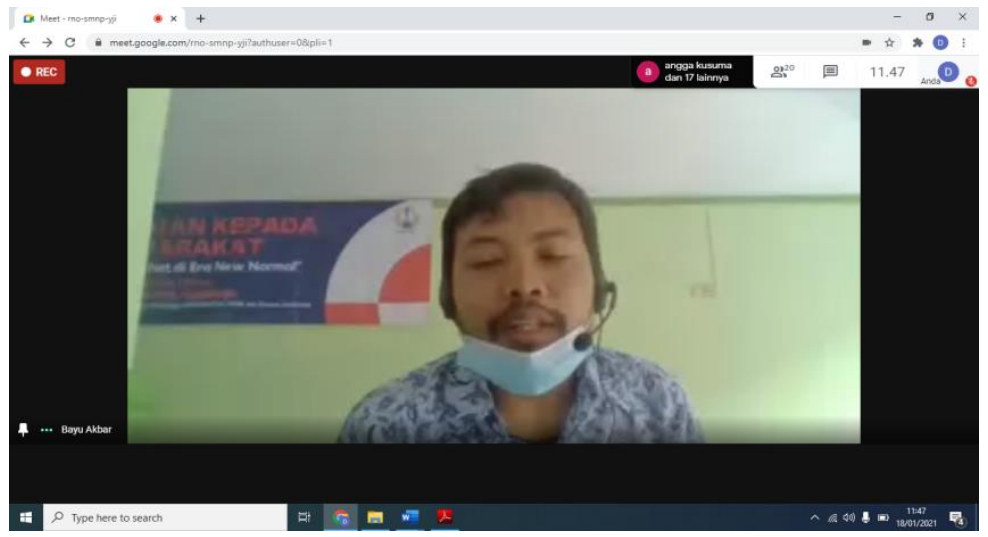

Gambar 5. Diskusi dengan peserta

\section{Kesimpulan}

Kegiatan Pengabdian Pada Masyarakat ini memperoleh sebuah manfaat yaitu dari segi peningkatan pengetahuan guru-guru di SMPN 1 Perak Jombang tentang pentingnya meningkatkan kekebalan tubuh di era pandemic. Metode yang bisa digunakan yaitu dengan mengkonsumsi makanan bergizi dan rutin mengkonsumsi Vitamin C.Kegiatan ini mendapat respon yang positif dari guru-guru dan hasil dari kegiatan tersebut direncanakan akan disosialisasikan pada peserta didik melalui pembelajaran.

\section{Daftar Referensi}

Adriani, M \& Wirjatmadi, B. 2012. Pengantar Gizi Masyarakat. Jakarta: Kencana Prenada Media Group. Agustina, Widya. 2015. Kandungan Vitamin C dan Uji Organoleptik Fruithgurt Kulit Buah Semangka dengan penambahan Gula Aren dan Kayu Secang. Naskah Publikasi. Universitas Muhammadiyah Surakarta.

Arisman, 2014. Gizi Dalam Daur Kehidupan. Jakarta: EGC.

Gombart, Adrian F., Adeline Pierre, and Silvia Maggini. "A review of micronutrients and the immune System-Working in harmony to reduce the risk of infection." Nutrients 12.1 (2020): 236.

https://covid19.go.id/peta-sebaran-covid19,accesed 1 Maret 2020.

Hui, David S., et al. "The continuing 2019-nCoV epidemic threat of novel coronaviruses to global healthThe latest 2019 novel coronavirus outbreak in Wuhan, China." International Journal of Infectious Diseases 91 (2020): 264-266.

Paules Cl, Marston HD, Fauci AS. Infeksi Coronavirus - Lebih dari Sekedar Pilek. JAMA.2020; 323 (8): 707-708. doi: 10.1001 / jama.2020.0757.

WHO. Naming the coronavirus disease (COVID-19) and the virus that cause it. https://www.who.int/emergencies/diseases/novel-coronavirus- 
GANDRUNG: Jurnal Pengabdian Kepada Masyarakat ISSN: 2721-6136 (Online)

2019/technicalguidance/naming-the-coronavirus-disease-(covid-2019)-and-the-virus-thatcauses-it. 4 December 2020

YIImaz, Cemile, and Vural Gökmen. "Neuroactive compounds in foods: occurrence, mechanism and potential health effects." Food Research International 128 (2020): 108744. 